\title{
An improved method for RNA isolation and cDNA library construction from immature seeds of Jatropha curcas L
}

\author{
Jatinder Singh Sangha*1,2, Keyu Gu1 , Jatinder Kaur ${ }^{3}$ and Zhongchao Yin ${ }^{1}$
}

\begin{abstract}
Background: RNA quality and quantity is sometimes unsuitable for cDNA library construction, from plant seeds rich in oil, polysaccharides and other secondary metabolites. Seeds of jatropha (Jatropha curcas L.) are rich in fatty acids/lipids, storage proteins, polysaccharides, and a number of other secondary metabolites that could either bind and/or coprecipitate with RNA, making it unsuitable for downstream applications. Existing RNA isolation methods and commercial kits often fail to deliver high-quality total RNA from immature jatropha seeds for poly(A)+ RNA purification and cDNA synthesis.
\end{abstract}

Findings: A protocol has been developed for isolating good quality total RNA from immature jatropha seeds, whereby a combination of the CTAB based RNA extraction method and a silica column of a commercial plant RNA extraction kit is used. The extraction time was reduced from two days to about 3 hours and the RNA was suitable for poly $(A)^{+}$RNA purification, cDNA synthesis, CDNA library construction, RT-PCR, and Northern hybridization. Based on sequence information from selected clones and amplified PCR product, the CDNA library seems to be a good source of fulllength jatropha genes. The method was equally effective for isolating RNA from mustard and rice seeds.

Conclusions: This is a simple CTAB + silica column method to extract high quality RNA from oil rich immature jatropha seeds that is suitable for several downstream applications. This method takes less time for RNA extraction and is equally effective for other tissues where the quality and quantity of RNA is highly interfered by the presence of fatty acids, polysaccharides and polyphenols.

\section{Background}

Efficient isolation of high quality and quantity of total RNA from plants is highly desirable for the construction of a good-quality cDNA library. Several commercial reagents and kits are available for isolating RNA from plants (e.g., Trizol, Gibco-BRL Life Technologies; RNeasy plant kit, QIAGEN), but they are not always effective for all plant tissues, particularly for developing seeds of oil rich plants. Seeds from oilseed plants contain high levels of extractable lipids, polysaccharides and phenols and many other secondary metabolites that could interfere with RNA extraction, by degrading or co-precipitating with the extracted RNA [1-3]. Thus most RNA isolation methods either result in very low yields of RNA or form

* Correspondence: jsangha@nsac.ca

1 Temasek Life Sciences Laboratory, 1 Research Link, the National University of Singapore, Singapore 117604, Republic of Singapore

Full list of author information is available at the end of the article complexes with these contaminants resulting in low quality poly(A)+ RNA unsuitable for first strand cDNA synthesis and RT-PCR [4]. Such undesirable outcomes prompted researchers to develop new improved protocols for RNA extraction from several recalcitrant plant tissues [5-8].

Jatropha (Jatropha curcas L.) is a small tropical, woody plant belonging to the Euphorbiaceae family and is found in many tropical and subtropical countries. Even though the seeds of jatropha are highly toxic due to the protein 'curcin' and phorbol esters [9], almost all parts of this plant have been utilized, either in insecticides, green manure, soap making, medicine, just to name a few $[10,11]$. Jatropha seeds contain about $40 \%$ of oil enriched with both saturated [palmitic acid (16:0, 14.1\%) and stearic acid (18:0, 6.7\%)] and unsaturated [oleic acid $\left(18: 1 \Delta^{9}, 47.0 \%\right)$ and linoleic acid $\left.\left(18: 2 \Delta^{9,12}, 31.6 \%\right)\right]$ fatty 
acids [12-14]. During maturity, large amounts of fatty acids/lipids, several toxic compounds and other secondary metabolites are found in jatropha seeds particularly in four to five-week-old seeds [15]. These compounds are known to interfere directly with nucleic acid extraction from different biological samples [5,8]. In order to isolate high-quality intact RNA from such tissues, removal of these contaminating substances is necessary to prevent them from binding to nucleic acids [3,4]. With increasing demand for biofuel production, oil rich crops like jatropha are being explored through biotechnology. Information on the genome of jatropha is emerging and the functions of individual genes are being determined $[10,16]$. Isolation of high-quality RNA from immature jatropha seeds will be useful to construct an efficient cDNA library for understanding the molecular basis in seed oil improvement.

Cetyltrimethylammonium bromide (CTAB) based method was developed for RNA extraction from tissues containing high levels of polysaccharides and phenols [17]. The protocol is good for several recalcitrant plant tissues, but not always effective for the others, and therefore modified and improved as per requirement $[5,8,18]$. RNA extraction from jatropha developing seeds is difficult due to its complex properties. The published information on jatropha RNA isolation methods is very limited [19]. We tried several methods without successfully extracting a good amount of intact RNA from the seeds. We modified the CTAB RNA extraction method and combined it with silica column of RNeasy Plant Mini Kit (Qiagen, Germany) to develop a simple, quick and efficient protocol for isolating RNA from immature jatropha seed. The RNA extracted with this method was good for several downstream applications such as cDNA library construction, RT-PCR, gene isolation and Northern blot analysis. This method was equally good for seeds of mustard (Brassica spp.) and starchy rice (Oryza sativa).

\section{Methods}

\section{Plant tissue collection}

Immature jatropha (Jatropha curcas) seeds, at 4-5 weeks after fertilization were selected for total RNA extraction. Rice (Oryza sativa) seeds 21 days after fertilization and mustard (Brassica spp.) seeds 20 days after fertilization were also used. Before grinding, the kernels of immature jatropha seeds were separated from the seed shell, whereas for rice seed husks were removed using sterilized scissors or forceps and stored at $-80^{\circ} \mathrm{C}$ until use. Mustard seeds were removed from pods and used as such.

\section{Total RNA extraction method}

About $0.5 \mathrm{~g}$ of each seed sample was ground in liquid nitrogen using oven baked RNase-free mortar and pestle and the seed powder was then transferred to a pre-chilled
50-mL polypropylene (Falcon) tube. Five $\mathrm{mL}$ of preheated $\left(65^{\circ} \mathrm{C}\right)$ total RNA extraction buffer $\{2 \%(\mathrm{w} / \mathrm{v})$ CTAB (Sigma), 2\% (w/v) polyvinylpyrrolidone (PVP-40) (Sigma), $100 \mathrm{mM}$ Tris $\mathrm{HCl}$ (pH 8.0), $25 \mathrm{mM}$ EDTA, $2 \mathrm{M}$ $\mathrm{NaCl}, 0.1 \%$ spermidine (Sigma) and $2 \% \beta$-mercaptoethanol\} was added to the powdered seeds in each tube and samples were incubated for $30 \mathrm{~min}$ at $65^{\circ} \mathrm{C}$ in a water bath. The samples were placed on a vortex every 5 minutes to help tissue disruption and RNA extraction in the buffer. After incubation, an equal volume of Chloroform: Isoamylalcohol (24:1) was added to each sample in a fume hood and samples were mixed with a vortex for $30 \mathrm{sec}-$ onds. Thereafter the samples were centrifuged at $10,000 \mathrm{~g}$ for 20 minutes at $4^{\circ} \mathrm{C}$. The aqueous supernatant $(1 \mathrm{ml} /$ tube) above the white phase was carefully transferred into $2.0 \mathrm{~mL}$ RNase-free microcentrifuge tubes and an equal volume of Chloroform: Isoamylalcohol was added, mixed with a vortex and centrifuged in a desktop centrifuge at $10,000 \mathrm{~g}$ for 10 minutes at $4^{\circ} \mathrm{C}$. Without touching the white layer, the supernatant $(1.0 \mathrm{ml})$ was distributed to Rnase free $1.5 \mathrm{~mL}$ microcentrifuge tubes and $0.5 \mathrm{~mL}$ of 96-100\% ethanol was added. The supernatant-ethanol mixture was immediately loaded onto RNA binding columns $(0.75 \mathrm{~mL} /$ column) skipping filtration step (Qiagen RNA Mini extraction kit or any other similar kit) and spun at 10,000 $g$ for 30 seconds at room temperature. Leftover samples were loaded on the same columns to process the entire sample. The kit protocol was followed in subsequent steps to wash and desalt the samples bound with the silica membrane of the column. Finally, the RNA from each column was eluted using $50 \mu \mathrm{L}$ of RNase free water and stored at $-80^{\circ} \mathrm{C}$.

The quality of RNA was checked using a spectrophotometer (NanoDrop, Technologies Inc.) at two wavelength ratios of $A_{260 / 230}$ and $A_{260 / 280} \mathrm{~nm}$. The integrity of total RNA was determined by running samples on $1.2 \%$ denaturing agarose gel (Qiagen, RNeasy Mini Handbook). The intensity of $28 \mathrm{~S}$ and $18 \mathrm{~S}$ bands was quantified with Molecular Imaging software version 5.1 (Kodak, Rochester, NY). Aliquots of RNA were stored at $-80^{\circ} \mathrm{C}$.

\section{CDNA synthesis and cDNA library construction}

Poly(A)+ RNA was purified from total RNA of immature jatropha seeds using the Oligotex Midi mRNA kit (Qiagen, Germany), dissolved in RNase-free water, quantified with spectrophotometer (NanoDrop, Technologies Inc.), and stored at $-80^{\circ} \mathrm{C}$. The cDNA library was constructed using CloneMiner ${ }^{\text {ru }}$ cDNA Library Construction Kit (Invitrogen). The first strand of cDNA was synthesized using $5 \mu \mathrm{g}$ poly(A)+ RNA and converted into double strand cDNA (ds cDNA) containing att $\mathrm{B}$ sequences on each end followed by ligating attB1 adapter to the 5 end of cDNA. The cDNA was size fractionated by column chromatography to remove excess of primers, adapters, 
and small cDNAs. A non-radio labeled method was used to determine the cDNA yield. About 75-100 ng of cDNA obtained from different pooled fractions was used in sitespecific recombination and attB-flanked cDNA was cloned into an attP-containing donor vector (pDONR ${ }^{\mathrm{m}}$ 222). The BP reactions were transformed into ElectroMAX DH10B T1 phage resistant cells using an electroporator (Life technologies) and the transformed cells were plated on kanamycin $(50 \mu \mathrm{g} / \mathrm{mL})$ added LB agar media. Twenty positive clones were picked for verification of cDNA inserts. The mini-prepared plasmids were digested with BsrG1 enzyme (New England Biolabs) and electrophoresed on $1 \%$ agarose gel to determine average insert size of cDNA.

\section{Amplification of KAR gene using jatropha CDNA}

Primers from the Arabidopsis 3-ketoacyl-acyl carrier protein reductase, (AT1G24360) (KAR) involved in Fatty acid biosynthesis were selected from the GenBank database [20] for RT-PCR on jatropha seed cDNA. The amplification program for PCR consisted of an initial denaturation step at $94^{\circ} \mathrm{C}$ for $2 \mathrm{~min}$, followed by 35 cycles of $30 \mathrm{~s}$ denaturing $\left(94^{\circ} \mathrm{C}\right), 45 \mathrm{~s}$ annealing $\left(60^{\circ} \mathrm{C}\right), 1 \mathrm{~min}$ elongation $\left(72^{\circ} \mathrm{C}\right)$, and a final extension at $72^{\circ} \mathrm{C}$ for $5 \mathrm{~min}$. The amplified PCR product was visualized on agarose gel [21], and extracted from the gel using the QIAquick PCR purification kit (QIAGEN) to probe RNA blot. The PCR product was cloned into the Teasy vector (Promega) and sequenced using BigDye termination method with AB1377 sequencer (Applied Biosystems, Foster City, CA, USA). The sequenced product was confirmed by aligning with the Arabidopsis KAR nucleotide sequence at NCBI using BLAST.

\section{Northern blot analysis}

For Northern blotting, $15 \mu \mathrm{g}$ of RNA was isolated from immature jatropha seeds and leaves and fractionated on $1.2 \%$ agarose-formaldehyde denaturing gel (Qiagen
RNeasy Mini handbook). The RNA was blotted onto Hybond- $\mathrm{N}^{+}$nylon membranes (Amersham Pharmacia) and stained for visualization of the RNA bands [17]. The KAR cDNA probe generated using RT-PCR was labelled with [32P]-dCTP (GE Healthsciences). Pre-hybridization was for 3 hours and hybridization was for 16 hours at $65^{\circ} \mathrm{C}$ (Techne, Staffordshire UK). Filters were washed first (20 min) in buffer A $(2 \times$ SSC $+0.1 \%$ SDS $)$ and then Buffer B $(20 \mathrm{~min})$ in $(1 \times \mathrm{SSC}+0.1 \% \mathrm{SDS})$ and lastly $(30 \mathrm{~min})$ in buffer $\mathrm{C}(0.5 \times \mathrm{SSC}+0.1 \% \mathrm{SDS})$ at $65^{\circ} \mathrm{C}$. The bound probe was detected by exposing filters to KODAK Biomax MS Autoradiography Film using exposure cassettes at $-80^{\circ} \mathrm{C}$.

\section{Results and Discussion}

We tried a few protocols of RNA extraction based on CTAB $[5,7,8,17]$, acid guanidinium thiocyanate-phenolchloroform [22] and commercial RNA extraction kits to isolate total RNA from immature jatropha seeds (data not shown), but a high yield and quality of total RNA was only achieved with the modified method (II) reported in this study (Figure 1, Table 1). The simplified method II combined the CTAB based RNA extraction with RNA binding silica columns (RNeasy" Plant Mini Kit) and skipped the $\mathrm{LiCl}$ precipitation step to reduce the extraction time from two days to $\sim 3 \mathrm{~h}$.

RNA extracted with methods I (CTAB only), II (CTAB + silica column), and III (RNA extraction kit) were electrophoresed on denatured 1.2\% agarose gel to determine the quality and integrity of RNA bands (Figure 1). Ribosomal RNA bands (28S and 18S) of jatropha visualized on agarose gel showed integrity of the RNA with method II (Lane ii) and the average ratio of $28 \mathrm{~S}$ to $18 \mathrm{~S}$ was $1.73+0.08$ (Table 1) indicating least degradation which was a common problem with other methods we used. The CTAB based RNA extraction methods (including method I in this study) $[5,17]$ meant for recalcitrant tree plant tissues

Table 1: RNA yield and quality detected with spectrophotometer ${ }^{1}$

\begin{tabular}{|c|c|c|c|c|c|c|}
\hline Sample & Method2 & $A 260 / 280$ & $A 260 / 230$ & 28S:18S & RNA yield $(\mu \mathrm{g}) / \mathrm{FW} 3(\mathrm{~g})$ & Time \\
\hline \multirow[t]{2}{*}{ Jatropha } & 1 & $1.98 \pm 0.03$ & $1.91 \pm 0.02$ & $1.49 \pm 0.21$ & $124.30 \pm 8.82$ & $2 d$ \\
\hline & ॥ & $2.14 \pm 0.02$ & $2.25 \pm 0.04$ & $1.73 \pm 0.08$ & $282.42 \pm 12.91$ & $3 \mathrm{~h}$ \\
\hline \multirow[t]{2}{*}{ Mustard } & 1 & $1.85 \pm 0.04$ & $1.90 \pm 0.04$ & $1.24 \pm 0.08$ & $189.95 \pm 5.00$ & $2 d$ \\
\hline & ॥ & $2.05 \pm 0.04$ & $2.32 \pm 0.01$ & $1.68 \pm 0.18$ & $240.55 \pm 11.36$ & $3 \mathrm{~h}$ \\
\hline \multirow[t]{2}{*}{ Rice } & I & $1.94 \pm 0.03$ & $1.95 \pm 0.02$ & $1.55 \pm 0.22$ & $254.90 \pm 12.74$ & $2 d$ \\
\hline & $\|$ & $2.00 \pm 0.03$ & $2.20 \pm 0.02$ & $1.85 \pm 0.03$ & $335.35 \pm 17.36$ & $3 \mathrm{~h}$ \\
\hline
\end{tabular}

${ }^{1}$ Based on 4 individual samples

Method I, CTAB method with $\mathrm{LiCl}$ precipitation

${ }^{2}$ Method II, combination of CTAB based total RNA extraction method and RNeasy ${ }^{\circ}$ Plant Mini Kit (Qiagen, Germany).

FW, fresh weight,

3Based on Nanodrop readings. 


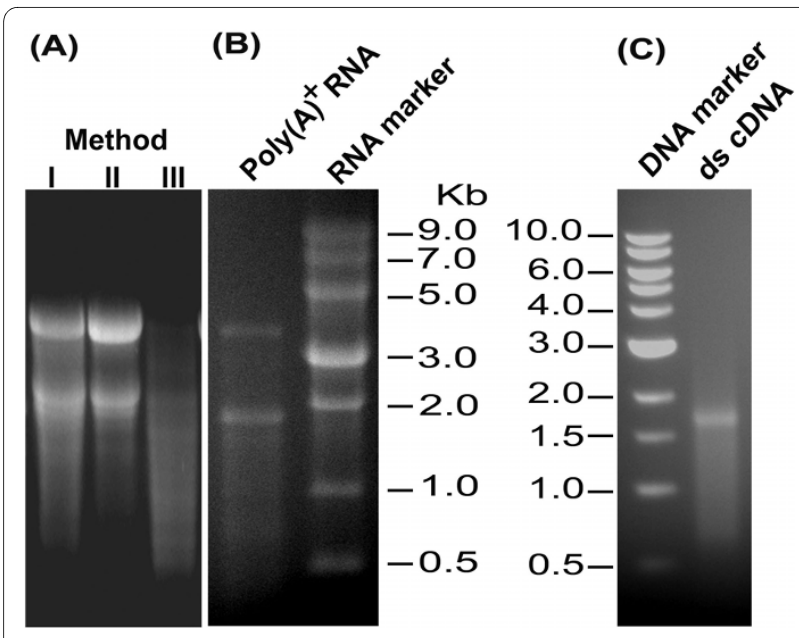

Figure 1 Detection of RNA extracted with different methods, Poly $(A)+$ RNA and the CDNA quality using agarose gel electrophoresis. Total RNA from jatropha immature seeds: (A) RNA extracted with method I(Lane i), RNA extracted with method II (Lane ii) and RNA extracted with Qiagen RNA Mini Kit (Lane iii). (B) Poly(A)+RNA purified from the total RNA using modified method II. (C) Double strand CDNA (ds CDNA) after size fractionation with column chromatography. The RNA and 1-kb DNA marker were from New England Biolabs. The image is representative of four independent experiments.

were time consuming, taking almost two days for completion and the purity was also compromised as the A260/230 ratio was lower than 2. 00. The average 28S:18S ratio was $1.49+0.21$, RNA showed smear on the gel and the bands were not sharp, indicating that the total RNA was still bound with contaminants or some degradation had occurred. Similar trends were observed with other published CTAB based methods and that involving phenol-guanidinium thiocyanate resulting in low RNA yield and quality (data not shown). The commercial kits for RNA extraction were also not successful as the silica columns were usually blocked with viscous extracts and the yield was extremely low and the quality was not good (Figure 1).

The improved RNA extraction method II is also efficient for other plant seeds rich in oil and starch as evident from the quality and quantity of RNA from mustard and rice seeds (Table 1). The ratio of $\mathrm{A}_{260 / 230}$ was higher than 2.0 for all these tissues indicating that the total RNA was of high purity without any contamination with polysaccharide compounds. Further, the $\mathrm{A}_{260 / 280}$ ratio was $>2.0$, indicating no contamination with proteins. The total RNA yield and both absorbance ratios for these tissues were low with method I.

The suitability of isolated RNA in downstream enzymatic procedures was also determined by constructing a cDNA library. The total RNA extracted with the modified method II produced a high quality poly(A)+ RNA using Oligotex Midi mRNA Kit (Qiagen) (Figure 1, Panel B). The yield of poly(A)+ RNA was about $3.8 \mu \mathrm{g}$ per $1 \mathrm{mg}$ total RNA. The poly $(\mathrm{A})+$ RNA was precipitated with isopropanol and NaAc to a concentration of $1 \mu \mathrm{g} / \mu \mathrm{L}$ for first-strand cDNA synthesis. Size fractionated doublestrand cDNA was visualized as a smear on the agarose gel (1.2\%) with a size ranging from $0.5 \mathrm{~kb}$ to $5 \mathrm{~kb}$ (Figure 1, Panel C). Entry library carrying cDNA inserts was transformed into phage resistant E. coli cells (Invitrogen) and the positive clones were selected on kanamycin added LB plates. This cDNA library consisted of $1 \times 10^{7}$ clones, which should be enough to represent most of the genes expressed in immature jatropha seeds.

To evaluate the cDNA library, plasmids were isolated from 20 randomly picked cDNA clones, digested with $B s r$ G1 enzyme (New England Biolabs) and separated on $1 \%$ agarose gel. The insert size of different cDNA clones ranged from $300 \mathrm{bp}$ to $2.3 \mathrm{~Kb}$ with an average size of 1.3 $\mathrm{Kb}$ (Figure 2). DNA sequencing also indicated that all these 20 clones carried cDNA inserts (data not shown). Using primers from Arabidopsis fatty acid biosysnthesis

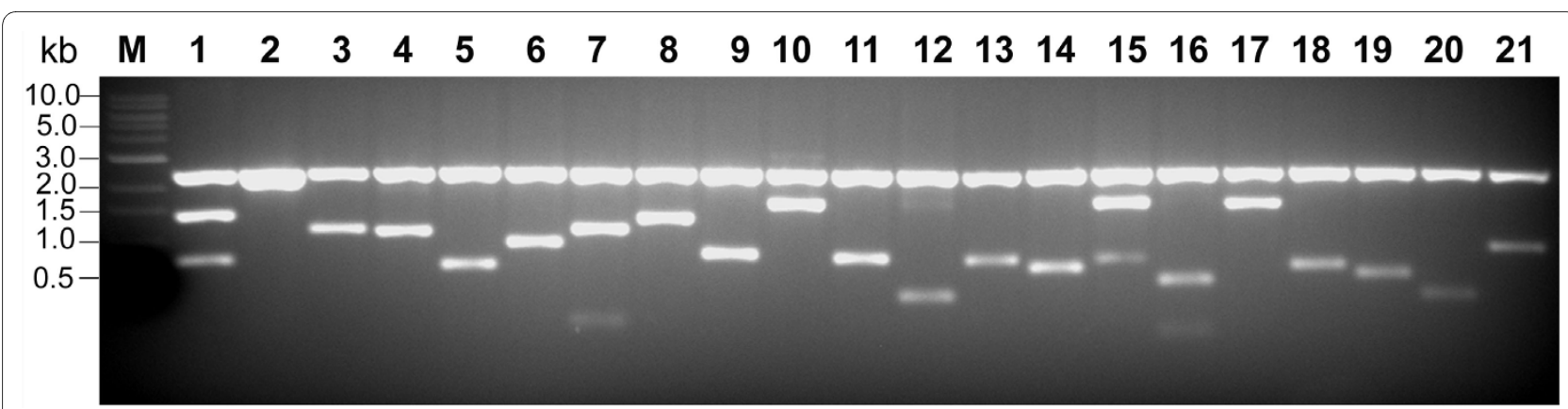

Figure 2 Evaluation of jatropha seed cDNA library. Poly $(A)+$ RNA was purified from total RNA extracted with method II and used for cDNA library construction using CloneMiner ${ }^{\mathrm{TM}} \mathrm{CDNA}$ Library Construction Kit (Invitrogen). Plasmid DNA of 20 positive clones was digested with BsrG1 enzyme (New England Biolabs) and electrophoresed on 1\% agarose gel to determine average insert size of cDNA. (Lane 1) 1-kb DNA marker (New England Biolabs); (lane 2) vector pDONR 222 (Invitrogen); (Lanes 3-22) randomly picked cDNA clones. Band at size $2.5 \mathrm{~Kb}$ is the vector backbone. cDNA insert of the clone in lane 3 has similar size as that of vector backbone, which did not separate in this gel electrophoresis. 
gene, 3-ketoacyl-acyl carrier protein reductase (KAR), RT-PCR was performed on jatropha cDNA. The amplified product was sequenced and used to probe northern blot carrying jatropha leaf and seed RNA extracted with method I and II. The RNA extracted with method II showed clear bands after hybridization while smeared bands appeared with extraction method I (Figure 3). The RT-PCR product was sequenced and compared with Arabidopsis KAR gene using NCBI Blast tools that showed a $67 \%$ similarity of amino acid sequence of the coding region (data not shown).

Silica columns and silica particles have been used previously in combination with CTAB [5] based methods to improve RNA extraction from various plant tissues. CTAB-based methods were however time consuming because of the $\mathrm{LiCl}$ step for RNA precipitation which was eliminated in the current method to reduce the time of RNA extraction from two days to $3 \mathrm{hrs}$. In fact, when the $\mathrm{LiCl}$ step was used, we found some degradation of the jatropha seed RNA (data not shown). RNA extraction buffer with insoluble polyvinylpyrrolidone (PVP-40) [7] efficiently removed interfering phenolic compounds thereby preventing blockage of kit columns. As the extract was passed through the silica columns, the RNA quality was further improved in on-column cleanup process.

The information on RNA extraction protocols is limited for jatropha. An acid phenol-silica particles based method was used to extract RNA from jatropha leaf and dry seeds [19]. The method, reported as quick and effective, however needed preparation of silica particles that took about $24 \mathrm{~h}$ and the yield was also low. The method

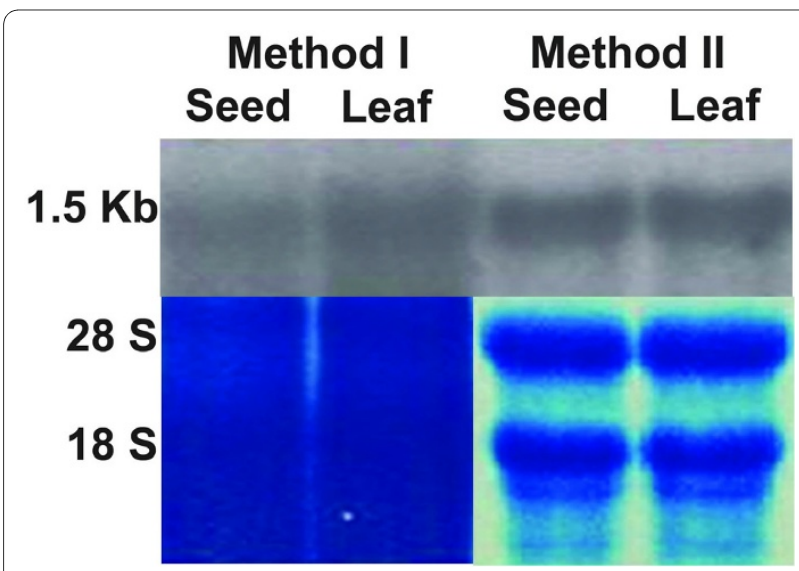

Figure 3 Northern hybridization of jatropha immature seed RNA with Ketoacyl ACP reductase (KAR) probe. RNA extracted with method I and II from jatropha leaves and seeds was fractionated on $1.2 \%$ agarose-formaldehyde denaturing gel and blotted onto Hybond$\mathrm{N}+$ nylon membrane. Stained blot was photographed and then hybridized with Ketoacyl ACP reductase (KAR) probe labelled with [32P]$\mathrm{dCTP}$. The hybridized bands were detected by exposing filters to KODAK Biomax MS Autoradiography Film at $-80^{\circ} \mathrm{C}$. The image is representative of four independent experiments. also required the use of toxic acid phenol for extracting RNA that has safety issues in handling and disposal. If improperly removed, RNA-phenol residual complex could interfere with reverse transcription reactions, smear on denaturing agarose gel and disturb RNA migration [23]. The method did not show any evidence for cDNA library construction or other downstream applications with jatropha RNA. Since phenol was not used in current procedure, the RNA was highly suitable for several downstream applications. The average RNA yield from the current method $(282.42 \pm 12.91 \mu \mathrm{g} / \mathrm{g} \mathrm{FW})$ and the band quality and ratio of $28 \mathrm{~S}$ and $18 \mathrm{~S}$ intensity is also good. Moreover, this method is straightforward in application as the supernatant is directly loaded on to the commercial silica columns, which is more convenient to work with.

\section{Conclusion}

The modified protocol is simple and highly effective for extracting good quality RNA from oil rich immature jatropha seeds as well as mustard and rice seeds. It should be equally useful for other tree plants for molecular characterization where the quality and quantity of RNA is highly dependent on the presence of lipids/fatty acids, polysaccharides and polyphenols.

\section{Competing interests \\ The authors declare that they have no competing interests.}

\section{Authors' contributions}

JSS conducted the experiments. JK drafted the manuscript. JSS and KG constructed CDNA library. ZY supervised and drafted the manuscript. All authors have read and approved the final manuscript.

\section{Acknowledgements}

This study was supported by the intramural research funds from Temasek Life Sciences Laboratory and a grant from Economic Development Board (EDB), Ministry of Trade and Industry, Republic of Singapore. The authors would like to thank Stephen Kelloway for reading the manuscript.

\section{Author Details}

1Temasek Life Sciences Laboratory, 1 Research Link, the National University of Singapore, Singapore 117604, Republic of Singapore, 2Department of Environmental Sciences, Nova Scotia Agricultural College, Truro, B2N5E3, NS, Canada and ${ }^{3}$ Department of Plant and Animal Sciences, Nova Scotia Agricultural College, Truro, B2N5E3, NS, Canada

Received: 20 December 2009 Accepted: 5 May 2010 Published: 5 May 2010

\section{References}

1. Logemann J, Schell J, Willmitzer L: Improved method for the isolation of RNA from plant tissues. Anal Biochem 1987, 163:16-20.

2. McNeil M, Darvill AG, Fry SC, Albersheim : Structure and function of the primary cell walls of plants. Annu Rev Biochem 1984, 53:625-663.

3. Asif $M H$, Dhawan $P$, Nath $P$ : A simple procedure for the isolation of high quality RNA from ripening banana fruit. Plant Mol Biol Rep 2000, 18:109-115.

4. Koonjul PPK, Brandt WF, Farrant JM, Lindsey GG: Inclusion of polyvinylpyrrolidone in the polymerase chain reaction reverses the inhibitory effects of polyphenolic contamination of RNA. Nucleic Acid Res 1999, 27:915-916. 
5. Iandolino AB, daSilva FG, Lim H, Choi H, Williams LE, Cook DR: High quality RNA, CDNA, and derived EST libraries from Grapevine (Vitis vinifera L.). Plant Mol Biol Rep 2004, 22:269-278.

6. Pandey RN, Adams RP, Flournoy LE: Inhibition of random amplified polymorphic DNAs (RAPDs) by plant polysaccharides. Plant Mol Biol Rep 1996, 14:17-22.

7. Claros MG, Cánovas FM: Rapid high quality RNA preparation from pine seedlings. Plant Mol Biol Rep 1998, 16:9-18.

8. Gasic K, Hernandez A, Korban SS: RNA extraction from different apple tissues rich in polyphenols and polysaccharides for CDNA library construction. Plant Mol Biol Rep 2004, 22:437a-437g.

9. Gubitz GM, Mittelbach M, Trabi M: Exploitation of the tropical oil seed plant Jatropha curcas L. Bioresour Technol 1998, 67:73.

10. Felke J: The poisonous principles of the seeds of Jatropha curcas Linn. Landw Versuchsw 1914, 82:427-430.

11. Lin J, Chen Y, Xu Y, Yan F, Tang L, Chen F: Cloning and expression of curcin, a ribosome-inactivating protein from the seeds of Jatropha curcas. Acta Botanica Sinica 2003, 45:858-863.

12. Augustus GDPS, Jayabalan M, Seiler GJ: Evaluation and bioinduction of energy components of Jatropha curcas. Biomass and Bioenergy 2002, 23:161-164

13. Bringi NY: Non-traditional oilseeds and oils of India. New Delhi, Oxford \& IBH Publishing Co. Pvt. Ltd; 1987

14. Makkar HPS, Becker K, Sporen F, Wink M: Studies on nutritive potential and toxic constituents of different provenances of Jatropha curcas. J Agric Food Chem 1997, 45:3152-3157.

15. Martínez-Herrera J, Siddhuraju P, Francis G, Dávila-Ortíz G, Becker K: Chemical composition, toxic/antimetabolic constituents, and effects of different treatments on their levels, in four provenances of Jatropha curcas L. from Mexico. Food Chem 2006, 96:80-89.

16. Luo M-J, Yang X-Y, Liu W-X, XU Y, Huang P, Yan F, Chen F: Expression, purification and anti-tumor activity of curcin. Acta Biochim Biophys Sin 2006, 38:663-669.

17. Chang S, Puryear J, Cairney J: A simple and efficient method for isolating RNA from pine trees. Plant Mol Biol Rep 1993, 11:113-116.

18. Kiefer E, Heller W, Ernst D: A simple and efficient protocol for isolation of functional RNA from plant tissues rich in secondary metabolites. Plant Mol Biol Rep 2000, 18:33-39.

19. Ding LW, Sun QY, Wang ZY, Sun YB, Xu ZF: Using silica particles to isolate total RNA from plant tissues recalcitrant to extraction in guanidine thiocyanate. Analytical Biochemistry 2008, 374:426-428.

20. National Center for Biotechnology Information (NCBI) GenBank [http:/ /www.ncbi.nlm.nih.gov]

21. Sambrook J, Fitsch EF, Maniatis T: Molecular Cloning: A Laboratory Manual. Cold Spring Harbor, Cold Spring Harbor Press; 1989.

22. Chomczynski P, Sacchi N: Single-step method of RNA isolation by acid guanidinium thiocyanate-phenol-chloroform extraction. Anal Biochem 1987, 162:156-159.

23. Ainsworth C: Isolation of RNA from floral tissue of Rumex acetosa (Sorrel). Plant Mol Biol Rep 1994, 12:198-203.

doi: $10.1186 / 1756-0500-3-126$

Cite this article as: Sangha et al., An improved method for RNA isolation and cDNA library construction from immature seeds of Jatropha curcas $L B M C$ Research Notes 2010, 3:126

\section{Submit your next manuscript to BioMed Central} and take full advantage of:

- Convenient online submission

- Thorough peer review

- No space constraints or color figure charges

- Immediate publication on acceptance

- Inclusion in PubMed, CAS, Scopus and Google Scholar

- Research which is freely available for redistribution

Submit your manuscript at www.biomedcentral.com/submit
C Biomed Central 